\title{
Effects of zooplankton Grazing on Phytoplankton succession in the River Nile, Egypt: an enclosures study
}

\author{
Adel A. Mageed ${ }^{1}$, Adel H. Konsowa ${ }^{1}$, Hammed M. Eladel ${ }^{2}$, \\ and Soaad A. Sabae ${ }^{1}$ \\ 1- National Institute of Oceanography and Fisheries, 101 Kasr Al-Ainy \\ St, Cairo, Egypt \\ 2- Botany Dep., Faculty of Science, Benha University, Benha, Egypt
}

\begin{abstract}
Tn situ three grazing experiments were carried out for determining the grazing 1 rate of zooplankton on phytoplankton species during autumn 2002, spring and summer 2003. Water samples from euphotic zone of the River Nile were inoculated with zooplankton organisms as its density in the Nile water and twice of that initial found in their natural field.

Phytoplankton communities in the different enclosures were dominated by Chlorophyceae, Bacillariophyceae and Cyanophyceae, whereas zooplankton organisms were represented by Rotifera, Cladocera, and Copepoda with the dominance of rotifers ( $>95 \%)$.

Grazing rate reached the maximal in $2^{\text {nd }}$ day of double field zooplankton enclosures during autumn and indicated that green algae and diatoms, especially Planktonema lauterbornii Schmidle, Dictosphaerium pulchellum Wood, Cyclotella operculata Kutz and Syndra ulna (Nitzsch) Ehr. were the most preferable algal cells grazed by zooplankton organisms (0.0599, 0.0174, 0.0530, $0.0371 / \mathrm{h}$, respectively). Moreover, zooplankton organisms grazed to large extent on Microcystis aeruginosa Kutz $\left(0.0504 \mathrm{~h}^{-1}\right)$ and Merismopedia glauca (Ehr.) Nageli (0.0105/h). Contrary, the grazing rate during spring and summer seasons was obviously high on blue greens, such as Chroococcus disperses Lemm., followed by diatoms and green algae, due to the abundance of rotifers during this period. Rotifers are able to graze even on blue green algae. The results revealed that, there was no evidence of strong negative effects on phytoplankton number, whereas the grazing rate decreases with increasing zooplankton number due to the nutrient regeneration by zooplankton, which induces phytoplankton growth.

Zooplankton abundance and community structure were important factors determining grazing rates in large rivers. Zooplankton density and phytoplankton can be increase two folds that found in Nile water especially in fish farms utilize River Nile water in aquaculture. Autumn season is the best time for zooplankton grazing on the different algal species inhabiting the River Nile.
\end{abstract}

Key Words: water quality, phytoplankton, zooplankton, grazing, River Nile. 


\section{INTRODUCTION}

Understanding of aquatic organisms is extremely important in the development of a water body management. In agitated water a larger reduction in grazing rate is observed at any water velocity, than in stagnant water (Miquelis et al., 1998). The grazing pressure of zooplankton was mainly on the nano- and picophytoplanktonic fraction in Lake Qarun-Egypt (El-Shabrawy \& Taha, 1999). The ratio between the number of algal cells grazed by zooplankton and the algal production was 132\% in August and $489 \%$ in September, due to the strong influence exerted by zooplankton on phytoplankton (Ravera and Scotto, 1999). Grazing rates in freshwater lakes (USA) dominated by some blue-greens were 10-fold lower than in water without these blue-greens, due to defense against grazing (Hambright et al., 2001). Phytoplankton densities in the freshwater fish farm (Egypt) were correlated with the densities of zooplankton where they can stimulate phytoplankton growth (Mageed and Konsowa, 2002). The combined impact of Cladocera and Copepoda led to a substantial decline in total phytoplankton biomass in Germany mesotrophic lakes (Sommer et al., 2003). In the River Nile (Egypt), centric diatoms are digested by zooplankton groups, and double cone diatoms are inedible by zooplankton, the daily growth rates of green algae are highly affected by grazing especially in enclosures containing great numbers of cladocerans (Khalifa 2004). The grazing impact of zooplankton community, especially copepods in the Pearl River estuary changed seasonally and spatially, being varied between $0.3 \%$ and $75 \%$ of the chlorophyll, or up to $104 \%$ of the daily phytoplankton production in summer and $21 \%$ in winter (Tan et al., 2004).

The major goal of this study was to evaluate the relationship between phytoplankton and zooplankton and their potential impact on water quality of the River Nile at El-Kanater El-Khayria.

\section{MATERIALS AND METHODS}

Three grazing experiments were conducted in situ during autumn 2002, spring and summer 2003. Up to 20 liters from the River Nile water at delta barrages $(10 \mathrm{Km}$ north Cairo) were taken from the euphotic zone of the Nile. Immediately on collection, the water was sieved through $44 \mu \mathrm{m}$ mesh net to remove zooplankton as possible. Three sets of 3 clear polyethylene bottles (20liters capacity) were filled with the Nile water. The first set represents the ungrazed aspirators (control), the second set was inoculated with freshly collected zooplankton from the same site as its density in the River Nile water ( $Z$ enclosure), while the third set was inoculated with zooplankton organisms twice of that initial found in their natural field (2Z enclosure). The containers were incubated under the surface water of the River Nile for 48 hours. Sampling for water quality analysis, phytoplankton and zooplankton identification and counting were withdrawn from the enclosures at 0 hour, 24 hours, and 48 hours of incubation. 
Water temperature, $\mathrm{pH}$ and Electrical conductivity were measured directly in the enclosures. The nutrient salts; ammonium, nitrite, nitrate, total organic nitrogen, orthophosphate, total organic phosphorus (TOP), and silicate were measured according to APHA (1995).

For phytoplankton, $500 \mathrm{ml}$ of water were preserved immediately in $4 \%$ formalin. The preserved samples were transferred in a clean graduated cylinder of $500 \mathrm{ml}$ capacity and few drops of Lugol's Iodine solution were added. The phytoplankton cells were allowed to settle, for 5 days. The supernatant was carefully siphoned off with a small plastic tube ending with a fine net of $20 \mu \mathrm{m}$ mesh diameter, until the samples were concentrated to $50 \mathrm{ml}$. The drop method was applied for counting and identification of different algal species as in APHA (1995).

Zooplankton samples were collected through a filtration of $2 \mathrm{~L}$ by a plankton net, with $55 \mu \mathrm{m}$ mesh size. The samples were preserved using $4 \%$ neutral formalin solution. In the laboratory, zooplankters were identified, and the number of zooplankton individuals (indv.) per litre was calculated.

Grazing rate (per hour) in each manipulation is the slope of the following equation "1": $r=b(Z C)+A$. Where " $r$ " is the realized algal growth rate (per hour), "ZC" is zooplankton concentration and A is the realized algal growth in the absence of zooplankton (per hour) (Draper \& Smith, 1981). Realized algal growth rate ( $\mathrm{r}$ ) was measured from changes in the number of cells of phytoplankton per hour during the manipulation according to Vanderploeg et al. (1988). Realized algal growth rate (r, per hour) was calculated as in the following equation " 2 ": $r=\ln \left(C_{1} / C_{0}\right) / T$. Where $\mathrm{C}_{0}$ and $\mathrm{C}_{1}$ are number of cells per liter, and $\mathrm{T}$ is the time period (hours) over which grazing is measured. The realized growth rates measured in each enclosure were used in equation " 1 " to calculate zooplankton grazing rate.

\section{Data analysis}

Analysis of variance (ANOVA), Pearson correlation between species of plankton and the different environmental variables, and regression between grazing rate and zooplankton concentration were carried out using Minitab ver. 12 under Windows. The data of phytoplankton, zooplankton and water quality variables were drawn up in the form of three matrices and were analyzed by Canonical Correspondence Analysis (CCA) using Brodgar Program, version 2.4.8 (Highland Statistics, 2005).

\section{RESULTS}

Physicochemical characteristics are shown in Table (1). The highest water temperature was recorded during summer, while the minimum was observed in autumn. Its values ranged from $20.5^{\circ} \mathrm{C}$ to $33.6^{\circ} \mathrm{C}$. $\mathrm{pH}$ values ranged between 7.91 and 8.80 in the three experiments. $\mathrm{pH}$ values were low at zero time compared to that recorded in the first and the second day at all sets of the 
experiments. Water conductivity was often high at zero time in comparison with the other times of the three experiments, with range of 288 to $411 \mu \mathrm{mohs} / \mathrm{Cm}$.

Table (1): Physicochemical characteristics during grazing experiments in field zooplankton (Z) and double field zooplankton number (2Z) enclosures.

\begin{tabular}{|c|c|c|c|c|c|c|c|c|c|c|}
\hline \multirow{2}{*}{ Parameters } & \multirow{2}{*}{ Season } & \multicolumn{3}{|c|}{ Control } & \multicolumn{3}{|c|}{ Z } & \multicolumn{3}{|c|}{$2 Z$} \\
\hline & & $0 \mathrm{~h}$. & $24 \mathrm{~h}$ & $48 \mathrm{~h}$ & $0 \mathrm{~h}$. & $24 \mathrm{~h}$ & $48 \mathrm{~h}$ & $0 \mathrm{~h}$. & $24 \mathrm{~h}$ & $48 \mathrm{~h}$ \\
\hline \multirow{3}{*}{$\begin{array}{c}\text { Water } \\
\text { Temperature }\end{array}$} & Autumn & 22.4 & 23.9 & 21.7 & 22.1 & 24.3 & 21.7 & 22.2 & 24.3 & 21.6 \\
\hline & Spring & 22.0 & 31.0 & 29.1 & 22.4 & 30.5 & 29.2 & 20.5 & 30.9 & 29.2 \\
\hline & Summer & 29.9 & 33.6 & 33.2 & 30.1 & 33.2 & 33.0 & 29.8 & 33.2 & 33.0 \\
\hline \multirow{3}{*}{$\mathrm{pH}$ values } & Autumn & 8.2 & 8.3 & 8.4 & 8.3 & 8.3 & 8.4 & 8.3 & 8.3 & 8.4 \\
\hline & Spring & 7.9 & 8.4 & 8.2 & 8.1 & 8.4 & 8.2 & 8.2 & 8.4 & 8.3 \\
\hline & Summer & 8.1 & 8.5 & 8.4 & 8.1 & 8.6 & 8.7 & 8.2 & 8.8 & 8.8 \\
\hline \multirow{3}{*}{$\begin{array}{l}\text { Conductivity } \\
\left(\mu \mathrm{mohs} \mathrm{Cm}^{-1}\right)\end{array}$} & Autumn & 390 & 332 & 365 & 361 & 338 & 353 & 411 & 351 & 354 \\
\hline & Spring & 350 & 350 & 349 & 353 & 352 & 347 & 351 & 352 & 348 \\
\hline & Summer & 324 & 320 & 321 & 335 & 328 & 304 & 339 & 288 & 297 \\
\hline \multirow{3}{*}{$\begin{array}{l}\text { Ammonium-N } \\
\left(\mu \mathrm{gL}^{-1}\right)\end{array}$} & Autumn & 39 & 42 & 25 & 48 & 30 & 30 & 49 & 45 & 38 \\
\hline & Spring & 47 & 53 & 50 & 63 & 91 & 30 & 81 & 75 & 48 \\
\hline & Summer & 105 & 97 & 105 & 116 & 112 & 106 & 124 & 108 & 100 \\
\hline \multirow{3}{*}{$\begin{array}{l}\text { Nitrite-N } \\
\left(\mu \mathrm{gL}^{-1}\right)\end{array}$} & Autumn & 4.0 & 5.7 & 3.3 & 4.8 & 7.6 & 2.0 & 4.2 & 7.2 & 4.9 \\
\hline & Spring & 14.5 & 12.7 & 9.2 & 13.8 & 8.5 & 11.9 & 9.0 & 11.9 & 14.5 \\
\hline & Summer & 2.3 & 2.2 & 2.5 & 1.6 & 2.7 & 3.2 & 2.1 & 2.7 & 3.5 \\
\hline \multirow{3}{*}{$\begin{array}{l}\text { Nitrate-N } \\
\left(\mu g L^{-1}\right)\end{array}$} & Autumn & 179 & 94 & 25 & 100 & 65 & 37 & 135 & 63 & 68 \\
\hline & Spring & 24 & 17 & 12 & 17 & 14 & 24 & 14 & 14 & 24 \\
\hline & Summer & 616 & 592 & 583 & 617 & 570 & 623 & 651 & 576 & 608 \\
\hline \multirow{3}{*}{$\begin{array}{l}\text { Total organic } \\
\text { nitrogen } \\
\left(\mathrm{mgL}^{-1}\right)\end{array}$} & Autumn & 4.0 & 3.9 & 1.1 & 3.5 & 1.2 & 1.4 & 3.8 & 14.5 & 2.2 \\
\hline & Spring & 3.3 & 4.8 & 7.5 & 10.6 & 6.9 & 9.6 & 2.6 & 2.9 & 5.0 \\
\hline & Summer & 1.4 & 4.5 & 23.3 & 7.2 & 9.9 & 3.8 & 6.3 & 6.1 & 5.5 \\
\hline \multirow{3}{*}{$\begin{array}{l}\text { Orthophosphate } \\
\qquad\left(\mu \mathrm{gL}^{-1}\right)\end{array}$} & Autumn & 14 & 4 & 2 & 7 & 15 & 3 & 8 & 6 & 16 \\
\hline & Spring & 39 & 17 & 18 & 22 & 46 & 49 & 17 & 35 & 37 \\
\hline & Summer & 71 & 53 & 54 & 55 & 54 & 42 & 89 & 35 & 107 \\
\hline \multirow{3}{*}{$\begin{array}{l}\text { Silicate } \\
\left(\mathrm{mgL}^{-1}\right)\end{array}$} & Autumn & 0.80 & 0.60 & 0.20 & 0.90 & 0.50 & 0.10 & 0.80 & 0.50 & 0.10 \\
\hline & Spring & 1.10 & 1.55 & 1.12 & 0.76 & 1.20 & 0.73 & 0.68 & 0.64 & 0.03 \\
\hline & Summer & 1.90 & 2.30 & 2.30 & 2.30 & 1.50 & 1.10 & 1.80 & 1.50 & 0.90 \\
\hline
\end{tabular}

Nitrate values had substantially increased the nitrite and ammonium concentrations. Ammonium and nitrate values were obviously high during summer rather than recorded in the other seasons. $\mathrm{NH}_{4}-\mathrm{N}$ concentrations were often decreased with time at the grazed enclosures. Its values ranged from 24.7 to $124.3 \mu \mathrm{g} / \mathrm{L}$. Nitrite concentrations varied from 1.6 to $14.5 \mu \mathrm{g} / \mathrm{L}$, while nitrate concentrations showed wide variations between 12.1 and $650.6 \mu \mathrm{g} / \mathrm{L}$. Total organic nitrogen (TON) exhibited a different pattern in each enclosure, but its 
values were usually low after 48 hours from the beginning of the experiment. It attained the maximum value of $14.5 \mathrm{mg} / \mathrm{L}$ in $2 \mathrm{Z}$ enclosures after 24 hours, while its minimum value of $1.2 \mathrm{mg} / \mathrm{L}$ occurred in control enclosure after 48 hours. Orthophosphate values decreased after 48 hours in all groups of enclosures, except a sharp increase at the last day of the third set. Its values showed a strong

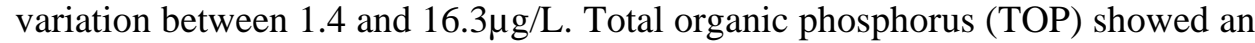
irregular distribution at most sets of this experiment. TOP attained the maximum value of $88.1 \mu \mathrm{g} / \mathrm{L}$ at $2 \mathrm{Z}$ set after 24 hours, while its minimum value of $11.5 \mu \mathrm{g} / \mathrm{L}$ occurred at the same set after 48 hours. Silicate had gradually decreased with increasing time. Its values fluctuated between 0.1 and $0.8 \mathrm{mg} / \mathrm{L}$.

Total phytoplankton crops (Table 2) increased with time as well as in autumn and summer compared to spring season. Chlorophyceae, Bacillariophyceae and Cyanophyceae were the prevailing classes during grazing experiments. Green algal crop attained its highest value of $8044 \times 10^{4}$ cells/ $\mathrm{L}$ after 48 hours at $2 \mathrm{Z}$ enclosures in summer, while lowest density of $336 \times 10^{4}$ cells/L was found at zero time of control in spring.

Table (2): Total phytoplankton density during grazing experiments (No. of $10^{4} / \mathrm{L}$ )

\begin{tabular}{|c|c|c|c|c|c|c|c|c|c|c|}
\hline \multirow{2}{*}{\multicolumn{2}{|c|}{ Phytoplankton classes }} & \multicolumn{3}{|c|}{ Control } & \multicolumn{3}{|c|}{ Z } & \multicolumn{3}{|c|}{$2 Z$} \\
\hline & & $0 \mathrm{~h}$. & $24 \mathrm{~h}$ & $48 \mathrm{~h}$ & $0 \mathrm{~h}$. & $24 \mathrm{~h}$ & $48 \mathrm{~h}$ & $0 \mathrm{~h}$. & $24 \mathrm{~h}$ & $48 \mathrm{~h}$ \\
\hline \multirow{4}{*}{$\begin{array}{l}\text { 罗 } \\
\text { 至 }\end{array}$} & Chlorophyceae & 991 & 1178 & 590 & 1102 & 903 & 2650 & 528 & 1248 & 5722 \\
\hline & Bacillariophyceae & 1010 & 884 & 264 & 1095 & 910 & 2090 & 597 & 1864 & 1987 \\
\hline & Cyanophyceae & 154 & 433 & 254 & 149 & 292 & 297 & 286 & 175 & 488 \\
\hline & Total phytoplankton & 2155 & 2495 & 1108 & 2346 & 2105 & 5037 & 1411 & 3287 & 8197 \\
\hline \multirow{4}{*}{ 品 } & Chlorophyceae & 336 & 582 & 856 & 476 & 757 & 712 & 346 & 550 & 2522 \\
\hline & Bacillariophyceae & 137 & 233 & 456 & 122 & 600 & 548 & 205 & 378 & 964 \\
\hline & Cyanophyceae & 220 & 347 & 410 & 159 & 167 & 368 & 266 & 140 & 377 \\
\hline & Total phytoplankton & 693 & 1162 & 1722 & 757 & 1524 & 1628 & 817 & 1068 & 3863 \\
\hline \multirow{4}{*}{ 㔽 } & Chlorophyceae & 553 & 1680 & 1868 & 1902 & 5260 & 5000 & 3106 & 5160 & 8044 \\
\hline & Bacillariophyceae & 251 & 93 & 276 & 532 & 999 & 1064 & 1395 & 1682 & 1076 \\
\hline & Cyanophyceae & 95 & 196 & 104 & 87 & 218 & 215 & 46 & 206 & 503 \\
\hline & Total phytoplankton & 899 & 1969 & 2248 & 2521 & 6477 & 6279 & 4547 & 7048 & 9623 \\
\hline
\end{tabular}

Diatom crops at the grazed enclosures were often higher than control and its values commonly increased with time. Bacillariophyceae attained minimum density $\left(93 \times 10^{4}\right.$ cells/L) after 24 hours at control enclosures, however its maximum crop $\left(2090 \times 10^{4}\right.$ cells/L) was counted after 48 hours at $\mathrm{Z}$ enclosures. The most dominant species among Bacillariophyceae were Melosira granulata (Ehr.) Ralfs, M. granulata var. angustissima Muller, Syndra ulna (Nitzsch) Ehr., Cyclotella ocellata Pant, and C. operculata Kutz. Numerical density of pennales diatom had obviously increased centrals forms in summer at the enclosures inoculated with zooplankton. 
Blue green algal crops were low compared to green algae and diatoms. Its lowest crop of $46 \times 10^{4}$ units/L was observed at zero time of $2 \mathrm{Z}$ enclosures while its highest of $503 \times 10^{4}$ units/L occurred after 48 hours of the same set. The dominant species of the blue green algae were Microcystis aeruginosa Kutz., $M$. elachista (W. \& G. S. West) Starmach and Merismopedia glauca (Ehr.) Nageli.

Chrysophyceae (Mallomonas sp.), Cryptophyceae (Cryptomonas ovata Ehr., Chromonas acuta Utermohl, C. nordstedtill Hansgirg), Dinophyceae (Peridinium cinctum Muller) and Euglenophyceae (Phacus curvicauda Swirenko) were rarely occurred during the grazing experiments.

Zooplankton organisms (Table 3) were represented by three groups namely Rotifera, Cladocera, and Copepoda. Rotifera was dominated by Keratella cochlearis (Gosse), Conochillus unicrnis Rousslet, while Cladocera was the second group dominated by Ceriodaphnia cornuta Richard and Alona intermedia Sars. Copepoda occupied the third group and was represented only by Thermocyclops sp. and its larval stages.

Table (3): Total number of zooplankton organisms (indiv./L) in each enclosure ( $\mathrm{Z}$ and $2 \mathrm{Z}$ ) and their dominant species in the three grazing experiments.

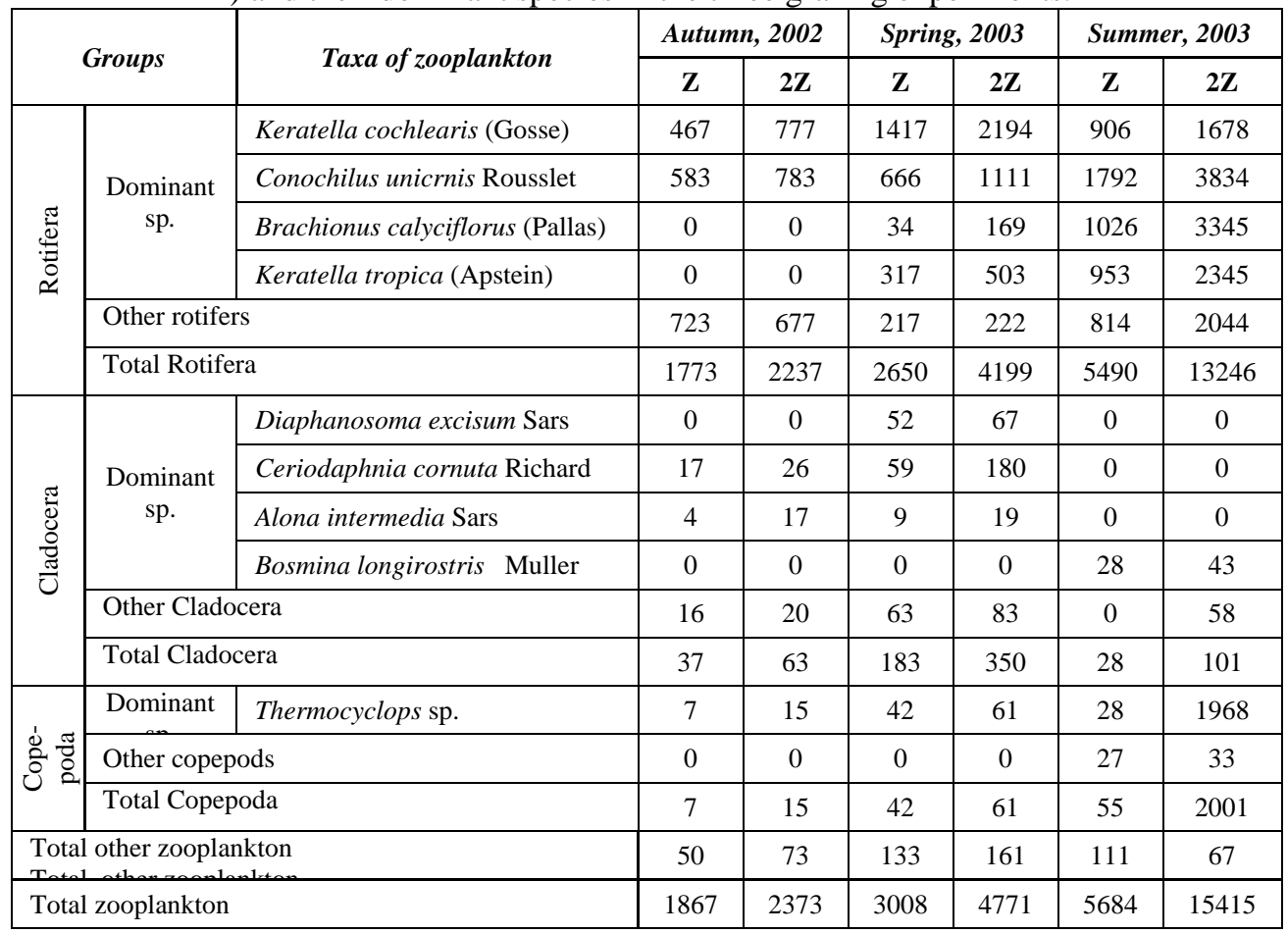

Zooplankton number was the highest during summer. The number during autumn was 1867 indiv./L in all $\mathrm{Z}$ sets and 2373 indiv./L in all $2 \mathrm{Z}$ enclosures, with the dominance of Conochilus unicornis. The number during spring experiment was 3008 indiv./L in $\mathrm{Z}$ set and 4771 indiv./L in $2 \mathrm{Z}$ 
enclosures, with the dominance of Keratella cochlearis. The zooplankton number during summer experiment was 5684 indiv./L in all $\mathrm{Z}$ sets and 15415 indiv./L in all $2 \mathrm{Z}$ groups, with the dominance of $C$. unicrnis, Brachionus calyciflorus, Keratella spp. and Thermocyclops sp.

Maximum grazing rate was observed during autumn (Table 4) chiefly in $2 \mathrm{Z}$ enclosures of second day. Also, its values were fairly high during $1^{\text {st }}$ day ( $\mathrm{Z}$ enclosures) in summer. In general; its value was very low in $2^{\text {nd }}$ day in $Z$ enclosures during the whole period of study. Grazing rate on Chlorophyceae revealed the preference of zooplankton grazing on Planktonema lauterbornii Schmidle and Dictosphaerium pulchellum Wood where its values reached $0.0599 / \mathrm{h}$ and $0.0174 / \mathrm{h}$ at $2 \mathrm{Z} \& \mathrm{Z}$ enclosures, respectively of $2^{\text {nd }}$ day. Also, grazing rate on diatoms indicated the tendency of zooplankton grazing on Cyclotella operculata Kutz and Syndra ulna (Nitzsch) Ehr. Its values were $0.0530 / \mathrm{h}$ and $0.0371 / \mathrm{h}$ in $\mathrm{Z}$ and $2 \mathrm{Z}$ enclosures, respectively. The dependence of zooplankon on Cyanobacteria was low compared to the previous two groups. Zooplankton organisms grazed to large extent on Microcystis aeruginosa Kutz and Merismopedia glauca (Ehr.) Nageli. The grazing rates on these blue green algae were 0.0504 and $0.0105 / \mathrm{h}$ in $2 \mathrm{Z}$ and $\mathrm{Z}$ enclosures during $2^{\text {nd }}$ and $1^{\text {st }}$ day respectively. Also, the grazing rate on the other groups of phytoplankton was very low except on Chromonas acuta Utermohl (0.0251/h) and Peridinium cinctum Muller $(0.0230 / \mathrm{h})$ during $1^{\text {st }}$ day of this experiment.

Analysis of variance (ANOVA) for the grazing rate of zooplankton concentration on total phytoplankton density was not significant for the three seasons. The difference in the grazing rate during the seasons was found between the grazing rate of the different phytoplankton species (not as total density) during autumn ( $\mathrm{p}=0.016)$, while it was non significant during spring and summer $(p=0.15$ and 0.18 , respectively). For grazing rate of the two zooplankton concentrations ( $\mathrm{Z}$ and $2 \mathrm{Z}$ ), ANOVA evaluated high significant difference during autumn and low difference during spring, while no significant difference during summer $(\mathrm{p}=0.01,0.8$, and 0.07 , respectively). 
Table (4): Grazing rate / hour in autumn, spring and summer seasons

\begin{tabular}{|l|c|c|c|c|}
\hline \multirow{5}{*}{ Species } & \multicolumn{2}{c|}{ First day } & \multicolumn{2}{c|}{ Second day } \\
\cline { 2 - 5 } & $\mathbf{Z}$ & $\mathbf{2 Z}$ & $\mathbf{Z}$ & $\mathbf{2 Z}$ \\
\hline Autumn & -0.002 & -0.009 & 0.022 & 0.060 \\
\hline Planktonema lauterbornii \\
\hline $\begin{array}{l}\text { Cyclotella operculata Kutz } \\
\text { Microcystis aeruginosa }\end{array}$ & 0.053 & 0.004 & -0.040 & 0.007 \\
\hline Spring & 0.000 & -0.047 & 0.021 & 0.050 \\
\hline Planktonema lauterbornii & -0.039 & -0.015 & 0.017 & 0.009 \\
\hline Oocystis parva W. \& G. S. West & - & 0.017 & - & -0.006 \\
\hline Cyclotella ocellata Pant & 0.020 & 0.002 & -0.004 & 0.006 \\
\hline Cyclotella operculata Kutz & 0.019 & 0.002 & -0.009 & 0.000 \\
\hline Chroococcus disperses Lemm & 0.032 & - & -0.001 & - \\
\hline Summer & \multicolumn{5}{|l|}{} \\
\hline Planktonema lauterbornii & 0.008 & 0.004 & -0.011 & -0.005 \\
\hline Cyclotella ocellata Pant & 0.005 & 0.004 & -0.003 & -0.002 \\
\hline Cyclotella operculata Kutz & 0.008 & 0.001 & -0.006 & 0.001 \\
\hline Chroococcus disperses Lemm. & 0.011 & 0.009 & -0.004 & -0.001 \\
\hline
\end{tabular}

Canonical correspondence analysis (CCA) for 8 environmental variables, 4 phytoplankton classes, and 6 dominant zooplankton species relationships of the data of the three experiments are displayed in Figure (1). CCA axis 1 (29.8\%) and axis 2 (20.8\%) explained a substantial proportion of the variation in the zooplankton-phytoplankton and environment relationships.

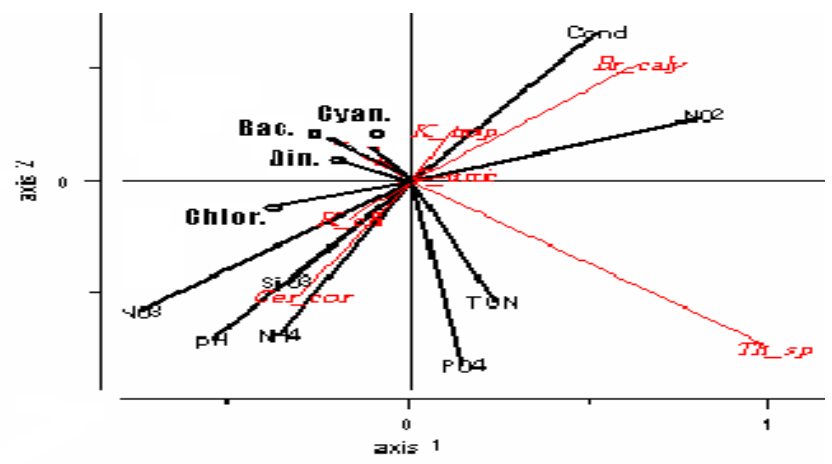

Fig.1. Canonical correspondence analysis (CCA) diagram with 6 zooplankters, 4 phytoplankton classes and 8 quantitative environmental variables. The phytoplankton classes are, Bac.= Bacillariophyceae, Cyan. $=$ Cyanophyceae, Din. $=$ Dinophyceae, Chlor. $=$ Chlorophyceae. Zooplankters are $K$. coch. $=$ Keratella cochlearis, $K$. trop. $=$ Keratella tropica, Br. caly. $=$ Brachionus calyciflorus, Con. $=$ Conochilus sp., Cer. cor. $=$ Ceriodaphnia cornuta, Th. sp. $=$ Thermocyclops sp. The environmental factors are $\mathrm{pH}, \mathrm{EC}=$ electrical conductivity, $\mathrm{PO}_{4}=$ orthophosphate-phosphorus, $\mathrm{NH}_{4}=$ ammonium, $\mathrm{NO}_{2}=$ Nitrite, $\mathrm{NO}_{3}=$ nitrate-nitrogen, $\mathrm{SiO}_{3}=$ Silicate, TON= total organic nitrogen. 
It is noted that axis 1 is more effective than axis 2 however they recorded eignvalues of 0.006 and 0.003 respectively. The most important factors explaining the zooplankters-phytoplankton variation on the first axis of CCA diagram were conductivity, nitrite, nitrate, $\mathrm{pH}$, and ammonia. Chlorophyceae, Brachionus calyciflorus, and Thermocyclops sp. were strongly related to axis 1 . The most important factors explaining the zooplankters variation on the second axis of CCA diagram were phosphorus and $\mathrm{pH}$. Bacillariophyceae, and Ceriodaphnia cornuta were strongly related to axis 2 .

\section{DISCUSSION}

In all grazing experiments, water temperature increases with increasing in phytoplankton crops where temperature increase more rapidly in turbid water regardless, of whether turbidity is mineral or organic matter (Ellis, 1989). $\mathrm{pH}$ values were low at zero time compared to the first and second day, due to the minimum phytoplankton crops at the first enclosures (zero time) of grazed and ungrazed groups ( $\mathrm{r}=0.71, \mathrm{p}=0.001)$, as reported by Elewa \& Mahdi (1988) at River Nile water. They pointed out that, increasing $\mathrm{pH}$ value at the River Nile was related to increase in primary production and photosynthetic activity of phytoplankton that uptake carbon dioxide from carbonate bicarbonate buffer system. Water conductivity decreased with increasing phytoplankton density. This result could be realized to phytoplankton consumption some of ionizable salts in solution with time $(\mathrm{r}=-0.52, \mathrm{p}=0.006)$ as reported by Konsowa and Taha (2002).

Ammonium concentrations were obviously high during summer compared to autumn and spring seasons. This is mainly realized to the flourishing of zooplankton organisms in hot season that responsible for excretion processes. This view agrees with Harris and Malej (1986) and McCarthy and Eppley (1972) who pointed to the importance of zooplankton excretion in the nitrogen cycle. On the other side, nitrate concentrations follow to a large extent the abundance of total phytoplankton crop $(r=0.50, p=0.01)$. However, orthophosphate concentrations were usually increase after 24 and 48 hours at the grazed enclosures compared with the ungrazed sets, while silicate contents were obviously decreased with time. This observation can be attributed to nutrients recycling by zooplankton that returned proportionally more phosphorus than silicon to the environment. This process was disadvantage for diatoms and benefit green algae. This view is confirmed by positive significant correlation between green algae and $\mathrm{PO}_{4}-\mathrm{P}(\mathrm{r}=0.52, \mathrm{p}=0.01)$ as reported by (Sommer, 1988). CCA analysis showed correlation between nitrate, Chlorophyceae and zooplankton species (Brachionus calyciflorus and Thermocyclops sp.). Lehman (1980) and Scavia \& Fahnenstiel (1984) observed that, nutrient regeneration by zooplankton might affect phytoplankton communities, depending on the regeneration rates of specific nutrients and the requirements of the different phytoplankton species. So zooplankton grazing and availability of nutrients 
regulate phytoplankton communities, but the relative strengths of these two factors vary seasonally.

Grazing rate indicated that, green algae and diatoms, especially Planktonema lauterbornii, Dictosphaerium pulchellum, Cyclotella operculata and Syndra ulna were the most preferable algal cells for zooplankton diets (0.0599, 0.0174, 0.0530 , and $0.0371 / \mathrm{h}$, respectively). Also, these organisms grazed to large extent on Microcystis aeruginosa $(0.0504 / \mathrm{h})$ and Merismopedia glauca (0.0105/h). This agrees with the findings of Fulton and Paerl (1987a \& b). They reported that, grazing rates of most herbivores were much higher for the diatom Melosira sp. than for similarly sized blue green algal filaments. Cyr and Pace (1992) found that the zooplankton grazing rate was $0.48-5.52 / \mathrm{h}$ on algae $<35 \mu \mathrm{m}$ in 16 lakes (USA). Contrary, the grazing rate during the spring and summer seasons, was obviously high on blue green algae such as Chroococcus disperses followed by diatoms \& green algae, due to the abundance of rotifers during this period. This view is confirmed by De Bernardi and Giussani (1990) who reported that rotifers are able to graze even on these toxin-producing species more successfully than cladocerans and copepods. This condition results in a peak of rotifer density, because they do not have to compete for this food source with the other zooplankton. Furthermore, studies on Cyanobacteriazooplankton interactions have failed to demonstrate toxic effects in the field (Haney, 1987). Also, complex assemblages of algae can support zooplankton growth rates and reproduction, even in environments dominated by Cyanophyceae (Fulton and Jones, 1991). Some selective filter feeders, like copepods, can differentiate between toxic and non toxic algae and are therefore less susceptible to blue greens (De-Mott and Moxter, 1991).

The highest significant difference (using ANOVA) in zooplankton grazing rate was found during autumn, corresponding to the lowest zooplankton number, compared with the grazing rate during spring and summer. This result indicates the impact of zooplankton nutrient regeneration which increases with zooplankton number increase, leading to grow of phytoplankton. Hunt and Matveev (2005) indicated that nutrients regenerated by zooplankton could be rapidly assimilated into phytoplankton growth. Zooplankton may regulate phytoplankton not only by grazing, but also by the re-supply of nutrients through excretion. Whether the recycling effects would be strong or not, would depend on the degree of phytoplankton nutrient limitation and on which nutrient is limiting. Regression analysis (Figure 2) for grazing rate against zooplankton concentration showed there was no evidence of strong negative effects on phytoplankton number, whereas the grazing rate decrease with increasing zooplankton number. 


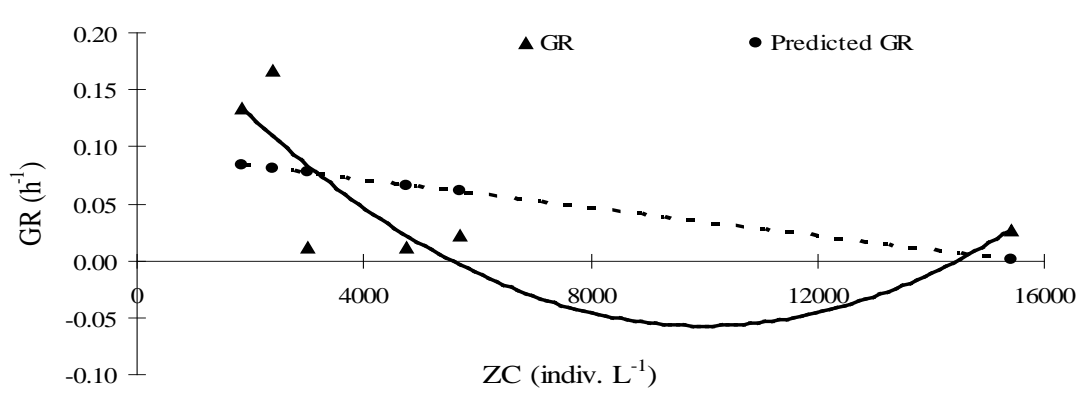

Figure 2: Grazing rate of zooplankton (GR, $h_{\text {Preth }}^{-1}$ Trespe line indiv. $\mathrm{L}^{-1}$ ) showing the observed and predicted grazing rate in a regression analysis.

In this study, grazing rates were sometimes negative values, due to exceed of algal growth rate in control enclosures compared to their values in the grazed set as also found by Gosselain et al. (1998).

This study illustrated the most preferable algal species for zooplankton and their grazing rate during the different season. Zooplankton density can be increase two folds that found in Nile water, in fish farms utilize Rivere Filile water in aquaculture. Autumn season is the best time for zooplankton grazing on the different algal species inhabiting River Nile.

\section{REFERENCES}

APHA (1995). Standard methods for the examination of water and wastewater. APHA. AWWA. WPCF. American Public Health Association 1015 pp. $15^{\text {th }}$ ed. NW Washington D.C.

Cyr, H. and Pace, M. (1992). Grazing by zooplankton and its relationship to community structure. Can. J. Fish. Aquat. Sci., 49: 1455-1464.

De Bernardi, R. and Giussani, G. (1990). Are blue green algae a suitable food for zooplankton? An overview. Hydrobiologia, 200/201: 29-41.

De-Mott, W. and Moxter, F. (1991). Foraging cyanobacteria by copepods: response to chemical defenses and resource abundance. Ecology, 72: 1820-1834. 
Draper, N. and Smith, H. (1981). Applied regression analysis. $2^{\text {nd }}$ ed. Wiley, New York, NY. 709pp.

Elewa, A. and Mahdi, M. (1988). Some limnological studies on the Nile water at Cairo. Egypt. Bull. Nat. Inst. Ocean. \& Fish, ARE, 14 (2): 141-152.

Ellis, K.V. (1989). Surface water pollution and its control. Environ. Heal. Eng. Univ., 366 pp.

El-Shabrawy, G. and Taha, O. (1999). Effects of grazing pressure of zooplankton on phytoplankton assemblage in Lake Qarun, El- Fayoum, Egypt. J. Aquat. Biol. \& Fish., 3 (3): 81-92.

Fulton, R. and Paerl, H. (1987a). Effects of colonial morphology on zooplankton utilization of algal resources during blue green algal (Microcystis aeruginosa) blooms. Limnol. Oceanogr., 32: 634-644.

Fulton, R. and Paerl, H. (1987b). Toxic and inhibitory effects of the blue green algae Microcystis aeruginosa on herbivorous zooplankton. J. Plankton. Res., 9: 837-855.

Fulton, R. and Jones, C. (1991). Growth and reproductive responses of daphnia to cyanobacterial blooms on the Potomac River. Int. Revue. Ges. Hydrobiol., 76: 5 - 19.

Gosselain, V.; Descy, J.; Viroux, L.; Joaquim-Justo, C.; Hammer, A.; Metens, A. and Schwetzer, S. (1998). Grazing by large river zooplankton; a key to summer potamoplankton decline? The case of the Meuse and Moselle rivers in 1994 and 1995. Hydrobiologia, 369/370: 199-216.

Hambright K.; Zohary, T.; Easton, J.; Azoulay, B. and Fishbein, T. (2001). Effects of zooplankton grazing and nutrients on the bloom-forming, $\mathrm{N}_{2-}$ fixing cyanobacterium Aphanizomenon in Lake Kinnert. J. Plankton Res., 23 (2): 165-174.

Haney, J. (1987). Field studies on zooplankton-Cyanobacteria interactions. N. Zeland J. Mar. Fresh. Wat. Res. 21: 467-475. 
Harris, R. and Malej, A. (1986). Dial patterns of ammonium excretion and grazing rhythms in Calanus helgolandicus in surface waters. Mar. Ecol. Progr. Series 31.

Highland Statistics Ltd. (2005). Update Note: Brodgar Ver. 2.4.8. Software Package for Multivariate Analysis and Multivariate Time Series Analysis. Highland Statistics Ltd., 120pp

Hunt, R. and Matveev, V. (2005). The effects of nutrients and zooplankton community structure on phytoplankton growth in a subtropical Australian reservoir: An enclosure study. Limnologica, 35: 90-101

Khalifa, N. (2004). Short-term effects of planktonic rotifers and cladocerans on phytoplankton of the River Nile, Intern. J. Environ. Studies, August, 61 (4): 403-412.

Konsowa, A. and Taha, O. (2002). Physicochemical characteristics and species composition of phytoplankton at the fresh water and estuary of Rosetta Branch of the Nile (Egypt): J. Egypt. Acad. Soc. Environ. Develop., 3 (1): 85-105.

Lehman, J. (1980). Release and cycling of nutrients between planktonic algae and herbivores. Limnol. Oceanogr., 25 (4): 620 - 632.

Mageed, A. and Konsowa, A. (2002). Relationship between phytoplankton, zooplankton and fish cultures in a freshwater fish farm, Egypt. J. Aquat. Biol. \& Fish., 6 (2): 183 - 206.

McCarthy, J. and Eppley, R. (1972). A comparison of chemical, isotopic and enzymatic methods for measuring nitrogen assimilation of marine phytoplankton. Limnol. Oceanogr., 17: 371 - 382.

Miquelis, A.; Rougier, C. and Pourriot, R. (1998). Impact of turbulence and turbidity on the grazing rate of the rotifer Brachionus calyciflorus (Pallas), Hydrobiolgia, 386: 203 - 211.

Ravera, O. and Scotto, S. (1999). A Sampler-incubator for studying zooplankton grazing and phytoplankton production. J. Limnol., 58 (1): 49 - 57. 
Scavia, D. and Fahnenstiel, G. (1984). Dynamics of Lake Michigan phytoplankton: mechanism controlling epilimnetic communities. J. Great Lakes Res., 13: 103 - 120.

Sommer U.; Sommer, F. ; Santer, B. ; Zollner, E. ; Jurgens, K. ; Jamieson, C. ; Boersma, M. and Gocke, K. (2003). Daphnia versus copepod impact on summer phytoplankton functional composition at both trophic levels. Oceologia, 135: 639 - 647

Sommer, U. (1988). Phytoplankton succession in microcosm experiments under simultaneous grazing pressure and resource limitation. Limnol. Oceanogr., 33: 1037- 1054.

Tan, S.; Cao, W.; Lin, Y.; Wang, G. and Li., S. (2004). Advances in the molecular systematic studies of marine planktonic crustaceans [In Chinese with English abstract]. Mar. Sci. Bull., 22 (5): 71 - 76. 